\title{
DESIGNING FOR THE “ABSENT USER”: KEEPING STUDENTS CLOSE TO END-USERS DURING DISTANT ARCHITECTURAL STUDIOS
}

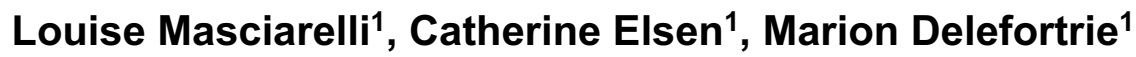 \\ ${ }^{1}$ University of Liège (BELGIUM)
}

\begin{abstract}
For long, architectural studios designed for advanced Master students have implemented numerous strategies to keep end-users at the core of the designed project, and to support the students through the process of learning how to design with an eye for end-users. Among those strategies, face-to-face encounters with (even a small) sample of potential end-users often reveals as a powerful way for students to open to end-users' perspectives and needs. Unfortunately, the covid19 crisis made such encounters impossible during the 2020-21 academic year. In such impoverished pedagogical context, how could students still design for the "absent user" during their architectural studio? This paper relates an experimental setting developed to help Master students in architectural engineering re-connect with end-users, even in the absence of such end-users. Four well-known user-centric design tools have been tested and their uses and added values have been captured through focus groups conducted with the students. The results reveal how the tools can (i) act in complementary ways to re-create some of the lost link; (ii) create coherence throughout the design process and (iii) can do so even beyond the early phases of the design process, i.e. beyond the temporality where face-to-face meetings traditionally occurred in non-distant settings.
\end{abstract}

Keywords: user-centred design; distant architectural studios; user-centric brainstorming; personas; user-journeys; ideation cards.

\section{INTRODUCTION}

Designers and users are inextricably related in regard of both the design process and the design output. Designers, and especially architects, have major impacts on the quality of the built environment, i.e. on the quality of life of many people. Designed artifacts, on the other hand, are meaningless unless endorsed by end-users, in power of taking ownership or rejecting these artifacts [1; 2]. Moreover, it is nowadays widely accepted that users "own the factual problem" [3], in other words are experts of their own personal experiences and issues associated with their personal situation. If the intertwined relationship between designers and users itself constitutes a crucial part of the design process, involving users into the design process becomes even more crucial to the project success [4-7]. The traditional model of architectural design seen as the result of a sole Master's artful persuasion [8] is therefore completely outdated and no longer practicable [9-11], especially in view of users' current willingness to integrate the process.

Considering this shift of practice, architectural studios designed for advanced Master students have implemented numerous strategies to keep end-users at the core of the designed project, and to support the students through the process of learning how to design with an eye for end-users. Among those strategies, face-to-face encounters with (even a small) sample of potential end-users (generally during the site visit or during the early phases of the design process) generally reveal as a powerful way for students to open to end-users' perspectives and needs. Unfortunately, the covid19 crisis made such encounters impossible during the 2020-21 academic year. This paper thus relates an experimental setting developed to help Master students in architectural engineering re-connect with end-users, even in the absence of such end-users.

\section{STATE-OF-THE-ART}

From an educational point of view, how do students in architecture apprehend future end-users, hypothetically using the buildings they design? What does the literature tell us in terms of best practices when it comes to the implementation of user-centred, inclusive design thorough architectural studios? How can we, as teachers, help the students grow an awareness for "prospective" end-users, generally absent and hypothetical, while still pushing them to tackle real, concrete design problems [12]? For 
obvious reasons of easiness of implementation, the majority of educational settings opt for design programmes that are completely fictitious and that never include any contact (even artificial) with potential end-users. This leads to students being disinterested in the demands and needs of real users [13], which can be considered detrimental on the long run. However, several pedagogical methods do exist to raise awareness and teach user-centred, inclusive design to aspiring architects. The first one described here (learner-centred design) essentially focuses on the student's capability to project into someone else's experiences and may include end-users, but rather as passive "informants" during the design process. The second one goes one step further and explores end-users' active engagement throughout the learning process.

\subsection{Learner-centred design and its techniques}

One of the first principles of inclusive, user-centred design is to dissolve the boundaries and categories that separate the designers and the end-users: "In order for environments to be compatible for everyone, an inclusive design approach is fundamental. " [12, p.1]. Following this viewpoint, students must experience and understand the environment from the end-user's point of view and then implement their design approach nurtured by this empathic appraisal of the end-users' realities. The goal for the students is therefore to understand and identify the thoughts, emotions, expectations and needs of end-users in order to find solutions, eventually by themselves. The learning process is done autonomously and is no longer just a matter of instructor's teaching: "learner-centred methods (...) shift the knowledge-making process from the instructor to the students" [12, p.5]. To apply learner-centred design's principles and achieve its objectives, various strategies and techniques can be implemented with architectural students, whether based on the realization of a project, a simulation of a situation or a role play, or even just a reflective analysis.

\subsubsection{Learning based on the completion of a project, or "project-based learning"}

The "project-based learning" (PBL) approach is one of the most widely used learning methods in the literature and in application in architectural education. This is certainly because it is also one of the most practical and easy to apply. Students are assigned a problem and/or a program for which they must collaborate, agree, and come up with a tangible solution that respects end-user requirements and needs, through an iterative design process. By proceeding so, the multiple potential ways of interacting with the design proposal are the ultimate concern of the students, which tends to improve the empathic relationship between the students themselves, and between the students and other (fictitious) protagonists [12].

In 2017, researchers Nishimura, Boda and Sakurai from the Department of Architecture at Niigata University implemented such a "project-based learning" approach through their architectural design studio but went beyond "simple" empathy: they designed the pedagogical setting so that students would be regularly in touch with real end-users [13]. Observing that the majority of design studios conducted within their university were based on fictitious projects during which the students would pay little attention to the demands and needs of the users, the researchers designed a PBL practice where "students are constantly confronted with the owners' demands, additional requirements of residents, construction costs, as well as feasibility and environmental conditions such as usability, safety for children and elderly people, efficient car parking, convenient maintenance, snow removal, universal design, and wood processing" [13, p. 591]. The work is all the more rewarding for the students as the project really materializes: every year since 2000, a Gangi (traditional Japanese wooden construction) has been built in partnership with the residents of the chosen neighborhood. This program is an annual success and the projects have been awarded repeatedly.

\subsubsection{Role play or simulation}

In many educational fields, it is common to find role-playing or simulation exercises. Through these methods, students become imbued with the characteristics of the roles they take on, in order to apply real or imaginary scenarios, representative of the discipline concerned [12, p. 5]. The experiences can consist in active involvement during which the students simulate one or more experiences, for instance disability experiences as illustrated in Figure 1 . The experiences can also be more passive and simulate situations with users presenting other psychological or social characteristics (gender, behavior, origins, cultures, etc.). In carrying out their PBL studio and applying their design process, students at Niigata 
University, without realizing it, played the role of actively participating professional architects in contact with residents [13].

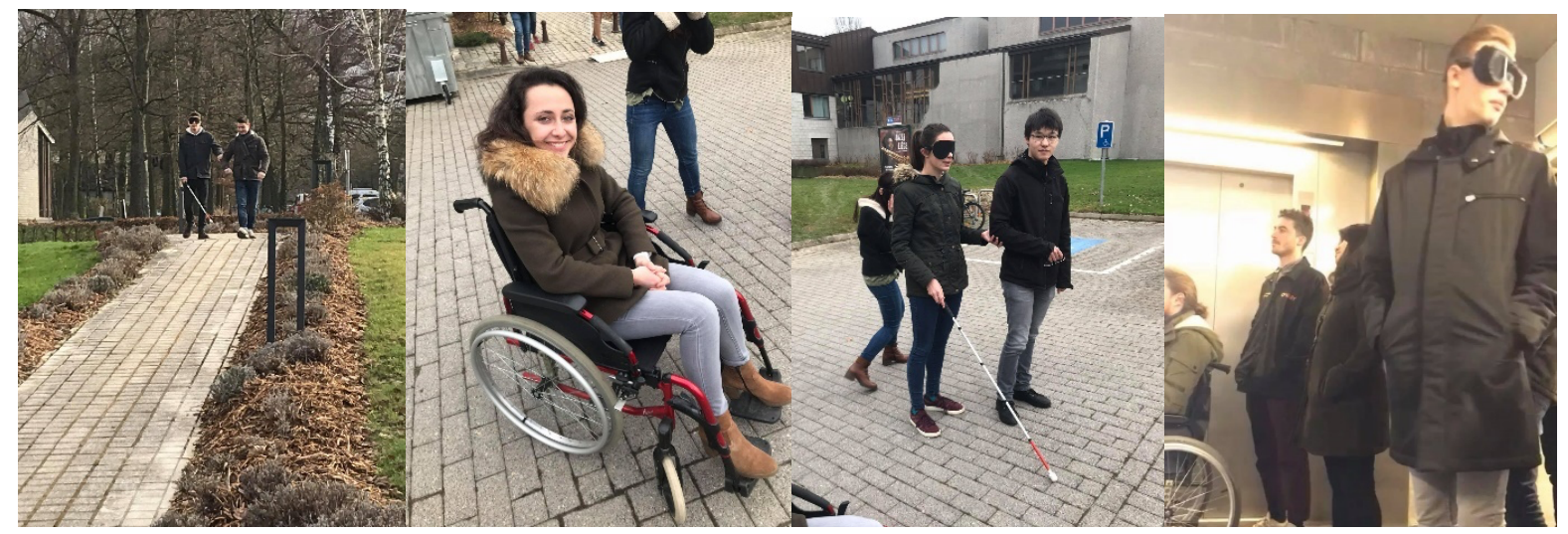

Figure 1 : Role play conducted by the second-year students from University of Liège as part of the Architectural Project Methodology course, as to better understand mobility impairment.

This type of exercise tends to challenge students' existing assumptions, beliefs, and functioning about themselves and others. The practice of role play is very symbolic in the context of teaching and raising awareness for inclusive design: it allows students to empathize with potential users by putting themselves in their shoes in order to better understand their situations, by directly involving their senses, their feelings, their emotions. This physical participation and commitment create strong experiences for the students and help them project into someone else's situation, and thus possibly propose design solution that better fit this situation [12].

\subsubsection{Reflective analysis}

Reflective analysis is a metacognitive practice of feedback that students can perform all along an architectural studio. Metacognition is defined as the ability to think and critically analyze one's way of thinking [14]. The objective for the students is therefore to apply a critical look with hindsight on the experience they have just lived, their (emotional) relationship to it and the posture they opt for, considering their learning and their achievements [12]. This often allows students to take a stand in relation to the choices they have made throughout their project, to express remorse or to point out gaps or problems related to the exercise itself. "In design disciplines, reflective practice is a natural process of the critical design, whereby the student develops his or her own project, supported by an ongoing dialogue with the instructor as they engage in a reflective conversation with the situation" [12, p. 5].

As part of a workshop conducted at Yasar University in Turkey, Altay and his colleagues set up a reflective analysis to be carried out following a PBL workshop, as to identify students' impressions concerning the success of the process implemented. They note: "it encouraged them to provide instant reflections on their actions. The main educational objective was to reflect on the outcomes and their experiences from the perspective of the workshop's initial intention: inclusive design awareness" [12, p.12]. The success of such a project ultimately depends on the commitment and involvement of the students themselves. In the absence of other "real" end-users available, the students were invited to use "their hearts, bodies and minds while engaging in the project at different levels" [12, p.16].

\subsection{End-users' engagement through participatory approaches}

Participatory approaches are more and more regularly used to make design students aware of usercentered challenges [15]. The literature relates a multitude of studies concerned with the application of these methods in the educational context and how it affects the students and the design process. As part of the Gangi construction project in the city of Niigata, students were at some point encouraged to collaborate with residents of the neighborhood. The experience of co-design and exchanges with endusers was found fundamental to the success of the project: "students are inclined to believe that the demands of the users must be central to their design, however, [other] factors conflict with each other" [13, p.591]. These exchanges allowed them to gather essential information on local history, inhabitants' culture and their habits during winter, enabling them to design coherent proposals that future users 
would criticize and discuss thereafter. The co-design phase with the residents has been considered fruitful and evaluated as extremely important by the students, especially to keep the end-users' related values in mind. It also constitutes a great collaboration opportunity for third year students who can train to practice and can consolidate skills that will serve them all along their professional career: "students can display and improve their creativity and communicative skills as professional engineers in a project with real-world implications" [13, p.589].

\section{METHODOLOGY}

\subsection{Pedagogical setting before covid 19}

At University of Liège, awareness to prospective end-users is raised as an important issue as soon as the Bachelor degree. During the three first years of the architectural engineering curriculum, students are mainly made aware of it through empathic PBL and role playing. During their two last years of Master degree, however, they are invited to raise their concerns for end-users mainly thanks to in-depth interviews, focus groups, in situ observations and co-creative sessions involving real end-users in realscale situations. Those encounters are usually organized during the two first weeks of an architectural studio (each studio spanning over 13 or 14 weeks at the rate of 8 hours' studio session per week), since the very first ideation steps of the design process are believed to be the most important ones when it comes to end-users' sensitization. Yet, we have to admit that this end-users' appraisal, although really powerful, tends to fade away as time passes, students having the tendency to prioritize other technical or structural issues as the final dead-line draws nearer.

A good illustration of this tendency stands in the 2019-2020 Master studio. Among other goals, teams of students had to design a bright new police headquarter. Most students being completely unaware of police field realities, at first a two-hours in-depth interview with a police inspector was organized in the University facilities. This experienced inspector had worked in several police precincts and had already taken part to numerous participatory processes organized by professional architects in the context of real-scale police headquarters design processes. He was thus considered as an expert of the "police needs" in general and was also used to interact with architects in charge of designing such buildings. During the interview, he mentioned a new national Decree suggesting (but not imposing) to renew the "architectural atmospheres" created in police buildings, as to make them more "welcoming and human, less stressful and impressive for citizens required to present themselves at the police precinct'. In the Decree, this suggestion essentially translated into entrances, lobbies and reception desks that would hide or even wipe out any strong signal remembering of repression, incarceration, danger, any defense or security systems prone to remind the citizens that they find themselves in the waiting room of some police station. In practice, the interviewed inspector explained to the students that this Decree would for instance encourage architects to design reception desks without any bullet-proof glass counters. Students reacted positively to this suggestion, considering that this would ease their design process and would allow them to create more qualitative spaces and atmospheres.

One week later, the students were invited for a three hours in situ visit and observation of a police headquarter nearby. During this site visit, they had the opportunity to observe, interact and ask questions to numerous other profiles: police officers, technicians in charge of the building maintenance; trainers in charge of police office dogs or even the cleaning lady in charge of the custody cells, that most of the students would see for the very first time in their life. Among their interactions, we recall a long conversation with the female worker in charge of the registrations. Asking her about what she thought of removing the bullet-proof glass that at that time still protected her desk, she reacted promptly: "I think this is a very bad idea. I do not fear any bullet, in our precinct it never happens. Gun violence is really rare. But this bullet-proof glass is a way for me to remain calm; it's a way for me to be protected from small things, for instance spits or unpleasant odors that some homeless people bring with them. If you remove my glass, I will be more stressed, I will cringe if something smells weird, I will be less cheerful and smiling. It will make the citizen experience less relaxed, and that is my job: to make people feel relaxed by being myself polite and casual, so that they would for some time forget a little bit about the complicated situations they are here for". Listening to her, some students wondered how they would balance the national Decree suggestion with this real-life, field experience. They obviously were challenged by the discrepancy between the theoretical, top-down suggestion and the bottom-up, dayto-day experiences. 
Nine weeks later, during the final jury, one would have expected that these strong experiences and reflective processes would somehow have impacted the project, one way or the other. Yet, we had to notice that the students showed no specific sensibility anymore for the entrance hall: the teams certainly offered functional solutions in that regard, but no different from any regular headquarters' entry hall. No additional comments nor efforts were made in terms of creating welcoming atmospheres, as suggested by the Decree, nor on the contrary in terms of protecting the desk officers' working conditions. The nice intentions had simply faded away, somehow forgotten for the benefit of "stronger" constraints, for instance in terms of facades' aesthetics, structural engineering, fire safety measures or the circulation design of the "convicted pathway", required to never cross the "regular citizen pathway".

\subsection{Pedagogical setting after covid 19}

One year later, the 2020-21 architectural design studio had shifted its program towards a "House of Music" with a theoretical capacity of 1800 persons. Most of the studio sessions had to be organized distantly, for covid-19 reasons; 6 teams of three to four students plus the teaching staff would hassle through distant design sessions using video-conference as well as software running on digital pads, allowing real-time sharing of distant drawing (one of these software being the result of University of Liège lab's research; for more information please refer to [16]). Encounters with end-users in this context were out of the question: no in situ observations could be organized; no in-depth interviews could be scheduled even remotely, as every cultural, music-related institution was completely shut off for several months, with employees less available and enthusiastic to share their experience considering their confined, unemployed situations.

In such impoverished pedagogical context, how could students still design for the "absent user" during their sessions of architectural studios? Facing this challenge, we decided to implement four well-known user-centric design tools (extracted from Lallemand's and Gronier's book [17]), hopefully triggering user centeredness even in the absence of any user. Thus, at week \#2 a users-centric brainstorming was organized, followed by a second workshop at week \#4, rather focusing on personas and their journeys (see Figure 3 below). Starting at week \#5, interested teams could participate to a third optional workshop using ideation cards. Eventually, after the final jury and after receiving their grades (as to avoid any form of bias towards teacher's desirability), each team took part to a reflective focus group, organized to capture students' thoughts and perceptions of the tools used during this pedagogical setting. Additional details of the protocol are summarized in Table 1.

Table 1: Details of the user-centred pedagogical setting.

\begin{tabular}{|c|c|c|c|c|}
\hline $\begin{array}{l}\text { Studio Session \# } \\
+ \text { Workshop title }\end{array}$ & Task(s) at hand & Method / Tool & Sample & Duration \\
\hline \multirow{2}{*}{$\begin{array}{l}\text { Session \#2 - } \\
\text { Workshop } 1 \text { (in } \\
\text { presence): } \\
\text { "Discovering the House of } \\
\text { Music end-users » }\end{array}$} & $\begin{array}{l}\text { Collective reflective process on the } \\
\text { potential end-users }\end{array}$ & $\begin{array}{l}\text { Users-centric } \\
\text { Brainstorming }\end{array}$ & $\begin{array}{l}\text { Whole class } \\
\text { (20 students) }\end{array}$ & $45 \min$ \\
\hline & $\begin{array}{l}\text { Team reflective process on the } \\
\text { end-users' potential impact on the } \\
\text { building, its spaces and circulations }\end{array}$ & $\begin{array}{l}\text { Users' journeys on } \\
\text { block diagram } \\
\text { (provided to the } \\
\text { students - see Fig. 3) }\end{array}$ & Per team & $45 \min$ \\
\hline \multirow{2}{*}{$\begin{array}{l}\text { Session \#4- } \\
\text { Workshop } \\
\text { presence): } \\
\text { "End-users' } \\
\text { Appropriation » }\end{array}$} & $\begin{array}{l}\text { Freely choosing three notable end- } \\
\text { users and creating one persona for } \\
\text { each }\end{array}$ & Personas & Per team & $45 \min$ \\
\hline & $\begin{array}{l}\text { Team reflective process on the } \\
\text { personas' potential impact on the } \\
\text { building, its spaces and circulations }\end{array}$ & $\begin{array}{l}\text { Personas' journeys on } \\
\text { block diagram } \\
\text { (provided to the } \\
\text { students - see Fig. 3) }\end{array}$ & Per team & $45 \min$ \\
\hline $\begin{array}{l}\text { Sessions \#5 or } 7 \\
\text { (depending on the team) - } \\
\text { Workshop } 3 \text { (distant): } \\
\text { "End-users' experiences } \\
\text { in the building" }\end{array}$ & $\begin{array}{l}\text { Project status report and Problem } \\
\text { solving exercise using ideation } \\
\text { cards }\end{array}$ & $\begin{array}{l}2 \mathrm{D} \quad \text { and } \\
\text { representations } \\
\text { ideation cards }\end{array}$ & $\begin{array}{l}\text { Interested } \\
\text { teams } \\
\text { (optional) }\end{array}$ & 1h15 / team \\
\hline $\begin{array}{l}\text { Session \#14 - Final Jury } \\
\text { (distant) }\end{array}$ & $\begin{array}{l}\text { Presentation and project' defense } \\
\text { in front of a jury }\end{array}$ & Diaporama & All teams & $\begin{array}{l}30 \quad \min \\
\text { presentation } \\
/ \text { team }\end{array}$ \\
\hline $\begin{array}{l}\text { After the semester: final } \\
\text { focus groups (distant) }\end{array}$ & Students' feedback & $\begin{array}{l}\text { Semi-structured focus } \\
\text { group }\end{array}$ & Per team & $\begin{array}{l}45 \min / \\
\text { team }\end{array}$ \\
\hline
\end{tabular}




\section{RESULTS}

The Table 2 below summarizes the students' feedback, as collected during the focus groups. As to avoid any bias of desirability or any pressure felt in regard of the teaching staff, these focus groups were organized at the end of the semester, after the final jury and after providing grades to the teams. The focus groups were conducted by one of the co-authors, herself an older Master student at that time (but not part of the teaching staff nor taking part to the class herself), as to allow the students a complete freedom of speech. All focus groups were later anonymized, as to avoid any possible post-identification (also for the other co-author, herself part of the teaching staff).

Table 2: Summary of the students' feedback, as collected during the focus groups

\begin{tabular}{|c|c|c|c|c|c|c|c|c|c|}
\hline \multirow[b]{2}{*}{ Possible answers: } & \multicolumn{3}{|c|}{$\begin{array}{l}\text { Users-centric Brainstorming } \\
\mathrm{N}=\mathbf{2 0}\end{array}$} & \multicolumn{3}{|c|}{$\begin{array}{c}\text { Personas and Personas' } \\
\text { journeys } \mathrm{N}=\mathbf{2 0}\end{array}$} & \multicolumn{3}{|c|}{$\begin{array}{c}\text { Ideation Cards ( } 2 \text { teams } \\
\text { only } \mathrm{N}=6 \text { ) }\end{array}$} \\
\hline & Yes & I don't know & No & Yes & I don't know & No & Yes & I don't know & No \\
\hline $\begin{array}{l}\text { Possible answers } \\
\text { for the questions } \\
\text { about using a tool: }\end{array}$ & Yes & $\begin{array}{c}\text { Already } \\
\text { heard about } \\
\text { but never } \\
\text { used myself }\end{array}$ & $\begin{array}{l}\text { Never } \\
\text { heard } \\
\text { about, } \\
\text { never } \\
\text { used }\end{array}$ & Yes & $\begin{array}{c}\text { Already heard } \\
\text { about but } \\
\text { never used } \\
\text { myself }\end{array}$ & $\begin{array}{l}\text { Never } \\
\text { heard } \\
\text { about, } \\
\text { never } \\
\text { used }\end{array}$ & Yes & $\begin{array}{c}\text { Already } \\
\text { heard about } \\
\text { but never } \\
\text { used myself }\end{array}$ & $\begin{array}{l}\text { Never } \\
\text { heard } \\
\text { about, } \\
\text { never } \\
\text { used }\end{array}$ \\
\hline $\begin{array}{l}\text { Did you already use } \\
\text { this tool before? }\end{array}$ & 20 & 0 & 0 & 3 & 8 & 9 & 0 & 1 & 5 \\
\hline $\begin{array}{l}\text { Did you find it useful } \\
\text { in this particular } \\
\text { stage of the design } \\
\text { process }\end{array}$ & 17 & 3 & 0 & 19 & 1 & 0 & 6 & 0 & 0 \\
\hline $\begin{array}{l}\text { Did you use the } \\
\text { results of this } \\
\text { workshop later on } \\
\text { during the project? }\end{array}$ & 20 & 0 & 0 & 17 & 3 & 0 & 6 & 0 & 0 \\
\hline $\begin{array}{l}\text { Do you think you will } \\
\text { use such a tool } \\
\text { again in the future? }\end{array}$ & 20 & 0 & 0 & 11 & 7 & 2 & 3 & 3 & 0 \\
\hline $\begin{array}{l}\text { Do you think this } \\
\text { tool helped you take } \\
\text { into account the } \\
\text { user experience? }\end{array}$ & 19 & 1 & 0 & 17 & 3 & 0 & 6 & 0 & 0 \\
\hline $\begin{array}{l}\text { Do you think this } \\
\text { tool helped you } \\
\text { created new ideas? }\end{array}$ & 19 & 1 & 0 & 17 & 3 & 0 & 6 & 0 & 0 \\
\hline
\end{tabular}

In this paper, considering length's constraints, we will only focus on the main results collected in regard of the four main tools implemented in an effort to raise some awareness towards end-users.

\subsection{Users-centric brainstorming}

The Brainstorming itself was a tool well known by all students, who had already used it earlier (also through other classes of their curriculum). This one was yet "users-centred", i.e. the students were explicitly asked to create as many potential users' profiles as possible (see Figure 2), including eccentric and ridiculous ones, thus respecting the main fundamental rules of any brainstorming [17].

A large majority of them believed this tool was deployed at the right time, early in the project, as to stimulate group work and team spirit. Conducted at the level of the whole class ( 20 students), it allowed to reach a large panel of possible end-users, showing a variety of profiles and "categories". As one of the students comments during the focus groups: "there were a lot more end-users than we imagined. We had only imagined the general public, the staff and the artists. All these other end-users all had very specific needs that gave another dimension, a more realistic side to the projected design compared to real life". This variety of profiles goes hand-in-hand with a variety of needs and requirements, that were later reused differently by each team throughout the design process. During the focus groups, one of the students realized: "without this exercise, we would have tended to categorize the personas too broadly. Here by going it more precisely, we refine the project as well as possible at the level of the endusers and we use that information from the start. It's very useful because we can directly integrate it into the project". 
All students believed that they would use this tool again later on, given its perceived efficiency and its playful nature, allowing to lay the foundations and concepts of a project while still taking into account the large variety of possible end-users. As one of the students underlines: "brainstorming is a good way of realizing who you are going to design for, digging into profiles of people that you might tend to forget. You start discovering and travelling before you even design".

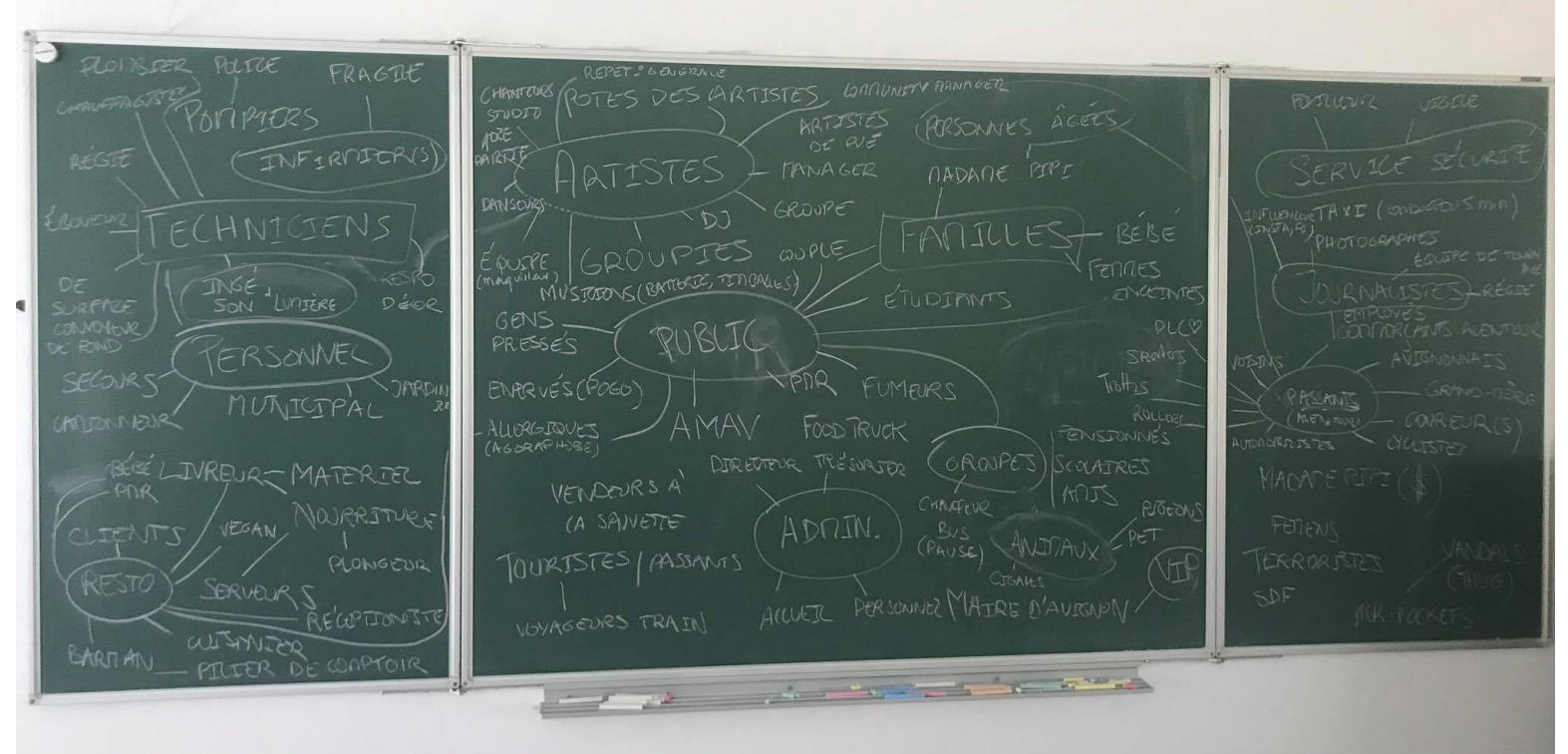

Figure 2: the result of the users-centric brainstorming conducted with the class.

\subsection{Personas and their journeys}

After generating dozens of possible end-users' profiles through the Brainstorming workshop, each team was invited to choose three of them, considered as the most important ones (or at least, the three profiles they would start working on first). For each of those profiles, the teams were invited to design a Persona following the general rules traditionally suggested on that matter (for more information, see [17]). Eventually, each team could assign one coloured post-it to each Persona, and then could create a "journey" for each Persona on basis of the program's block-diagram provided by the teaching staff (see Figure 3). This block-diagram is offered as a way to better understand the functional, organizational and circulatory constraints existing in between each area required by the program.
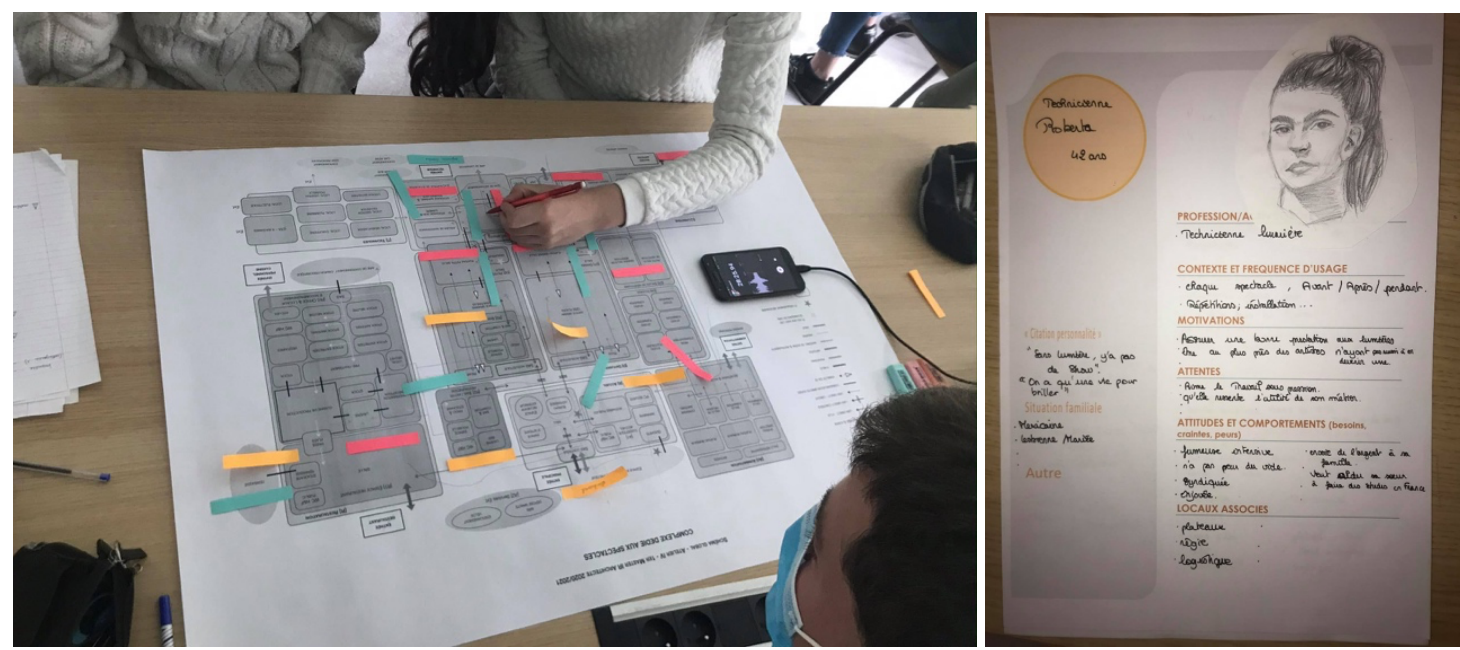

Figure 3 : On the left: one team of students positioning post-its on the block diagram provided to them, as to nurture Personas' journeys. Each color of post-it represents one chosen Persona. On the right: one example of Persona created by the students. 
Regarding those Personas and the possibility to create "user journeys" for each of them, only three students declared that they knew the tools and had already used them before, while 8 of them had only heard of them. Similarly to the brainstorming, almost all students believed that this set of tools was used at the right time of the semester, allowing them to better understand the needs of the end-users, handin-hand with the constraints associated with the program, pushing them to integrate those needs as soon as possible. As one of the students mentions: "the points of attention given to each persona in relation to their constraints forced us from the start to integrate little things that we often notice only at the end. It forces us to integrate them sooner and we therefore no longer need to repeat these points later".

$85 \%$ of the students considered the set of tools as beneficial, helping them to generate new ideas in regard of their project. They referred again to those personas later on during the project, consciously or unconsciously, as underlined by one of them: "unconsciously, the personas came back to mind when designing. Such user-centred design makes it possible to better understand each user and take their journey into account". Considering the journeys structured on basis of the block diagram, one student underlines: "it helped us see their interaction with the building via the functional diagram; the post-it notes help to see the circuits that we had to pay attention to when we were designing the building". Implemented jointly with the Persona, such user journey gains in specificity. Several students underlined that fact: "here the circuits are not only lines on a plan. By putting names, faces on the users, it forces us to see the design as a story"; "using personas allows us to create architecture as a story".

During the focus groups, each team at least once used terms like "it helps you put yourself in their shoes"; one of the students even commented: "it appeals to your senses, you have to make sure that everything goes well for him". The notion of sensoriality indeed seems omnipresent: all teams appeal to notions related to sensations, movements, experiences and eventually at some point express how they would live the experience in their building at the time of design, in a fictitious way. Thus, it seems that these tools were helpful to push the students to project themselves into the building they were designing, either as an architect and as the personas they had chosen to work on.

Considering future use, 11 students out of 20 think they will use such tools again in the future, while 7 comment that they would consider using it, but only for large-scale projects with a wide variety of endusers. Two of them, eventually, believed that they implement this way of working already naturally, without having to resort to a persona per se to reach similar outcomes.

\subsection{Problem solving using Ideation Cards}

Eventually, a third (online) workshop was suggested, optionally, to the teams that were tempted to use a third tool, namely a set of Ideation Cards defined on basis of Lallemand and Gronier's work [17]. This third workshop happened during the second Belgian confinement and could thus unfortunately only be organized remotely. It also happened later on during the semester, when most of the teams felt timepressure and preferred to focus on the detailed phases of the design process. Thus, only two teams (of three members each) decided to take part to this third workshop.

Globally speaking, ideation cards were not well known, as only one student had heard about them but never used them. All the students felt this problem-solving tool was useful, even if deployed later in the process, because it helped them take a step back from technical requirements and help refocus the team's attention on fundamental intentions and concepts, mainly related to the end-users of their building. As one of the students recalls: "workshop 3 took place at a key moment because we were more in the technique and the structure, and this session allowed us to remember why we were doing this project and also to re-motivate us. It boosted the group". The ideas and work carried out during this third workshop was later greatly exploited by the students, both through their final project defence, and through the technical, formal and functional sheets provided with their final presentation.

All the students considered that they would use this tool again, especially in a similar context where there would be a need to take a step back from a technical-oriented phase of the design process. That being said, half of them considered that the use of such a tool requires someone external to the project and to the team, as to supervise and lead the workshop and in order to reach full effectiveness. 


\section{CONCLUSIONS}

The set of tools used in the covid-19 situation, where no contact with end-users nor in situ observations were allowed, certainly proved useful to re-create some connection with prospective, even fictitious endusers. As one of the students underlines: "of course it would have been better to do the project with the inhabitants of the neighbourhood for example and to discuss it with them, but it was impossible to do so" and thus the workshops were considered as efficient in substitution.

Although the Personas, their journeys and possible experiences (as illustrated in the ideation cards) remain fictional, fragmented views of abstract end-users, we consider that they still achieved the expected goals, that is re-creating some of the lost link with absent, unattainable end-users. Interestingly, these tools also re-created a sense of coherence throughout the design process. They helped the students "keep their Personas in sight" even beyond the early phases of the design process, thus beyond the temporality where face-to-face encounters with "real" end-users would traditionally occur in prior, non-distant settings. Even though the insights gained through such artificial end-users certainly are less detailed, less situated and rich than insights collected through face-to-face encounters, we have to observe that they tend to stick longer, side-by-side with rather technical considerations. While the ephemeral encounters with real end-users tend to fade away as weeks pass, the rather simplistic image of the Personas pinned in the students' dorms would drive more consistently their design processes until their very late stages.

Obviously, results observed in this singular pedagogical setting should be considered with some caution: given the 2020-21 program (a "House of Music"), every student could probably lean on personal, previous experiences (of listening to music, of attending a concert, a festival and so on) as to support the design process (contrary to the case of designing a police headquarter, much less familiar to the students). Thus, the students' past experiences, their culture, their origin, their way of living, their past encounters with musical and cultural equipments and spaces certainly did shape and perhaps ease their appraisal of this year's program. Additional research would thus be necessary to extend our results beyond the scope of this singular experiment.

In our perspective, yet, this "covid-19" architectural studio opens unexpected perspectives for nextyears' studios. Indeed, at first we designed this setting as some (hopefully) "one-time experiment"; at the beginning of the semester we did not consider the possibility to replicate such setting in back-tonormal situations. Retrospectively, the tools we implemented to tentatively fill a void eventually revealed as particularly powerful, considering their own limitations, and could actually in the future complement face-to-face, ephemeral end-users' encounters. Thus, users' centric brainstorming could be conducted prior to any site visit, as to dream the variety of end-users without any form of bias; the results of such brainstorm could then lead towards the selection of complementary profiles to meet, observe and interview on the field. Personas and journeys could later on be built on basis of on-site insights, and could later be frequently referred too, side-by-side with ideation cards, as a way to maintain coherence throughout the architectural design process; as a way for students to "create architecture as a story".

\section{ACKNOWLEDGEMENTS}

We would like to thank Prof. Pierre Leclercq, Xaviéra Calixte and Gaëlle Baudoux for their help and support throughout the architectural studio. We would like to thank all the students of the 2020-21 Master in Architectural Engineering, University of Liège, for their participation and willingness to share feedback and insights.

\section{REFERENCES}

[1] J.P.S. Siva \& K. London. "Investigating the role of client learning for successful architect-client relationships on private single dwelling projects". Architectural Eng. and Design Management, 7:3, pp.177-189, 2011.

[2] V. Biau, M. Fenker \& E. Macaire. « Les métiers de l'architecture et de l'urbanisme à l'épreuve de l'implication des habitants et des usagers ». In Cahiers Ramau 6, L'implication des habitants dans la fabrication de la ville. Métiers et pratiques en question. pp. 11-28, 2012. 
[3] I. Reymen, K. Dorst \& F. Smulders. "Co-evolution in design practice". In About : Designing. Analysing design meetings (J. McDonnell and P. Llyod, Eds). CRC Press, Taylor and Francis Group. 434 p., 2009.

[4] B. Lawson. How designers think - the design process demystified. Fourth Edition. Ed. Routledge, Architectural Press. 321 p., 2005.

[5] J. le Maire. L'architecture participative, essai de chronologie. Les Cahiers de la Cambre. Architecture, 3, pp. 123-132., 2005.

[6] D. Estevez \& M. Léglise. "Accountability and design", Int. J. of Design Sciences and Technology, 20:2, pp. 99-102, 2015.

[7] S. Sarkar \& J. Gero. "The Topology of Social Influence and the Dynamics of Design Product Adoption”. Design Computing and Cognition ‘16, Springer, pp. 653-665, 2017.

[8] R. Prost \& F. Chaslin. Pratiques de projet en architecture: le tournant silencieux: essai. Infolio, 250p., 2014.

[9] J. Albrecht. "Towards a theory of participation in architecture: an examination of humanistic planning theories". J. Arch.Ed. 42(1), pp. 24-31, 1988.

[10] E. Macaire. "Des architectes à l'épreuve de la participation". InVille éphémère, ville durable Nouveaux usages, nouveaux pouvoirs, (De Coninck et Deroubaix, Eds.), Ed. de l'œil d'Or, Paris, pp. 135-147, 2009.

[11] J. McDonnell \& P. Lloyd. "Beyond specification: A study of architect and client interaction". Design Studies, 35(4), pp. 327-52, 2014.

[12] B. Altay, G. Ballice, E. Bengisu, A.-K. Sevinç, \& E. Paykoç."Embracing student experience in inclusive design education through leaner-centred instruction". Internation Journal of Inclusive Education, 20(11), 1123-1141, 2016.

[13] S.-Y. Nishimura, S. Boda, \& N. Sakurai, N. "A Project Based Learning through International Collaboration with Students, Inhabitants and Local Professionals". Workd Engineering Education Forum (WEEF), pp. 589-592, 2017.

[14] L. Kaminskienè , V. Žydžiūnaitè, V. Jurgilè \& T. Ponomarenko. "Co-creation of Learning: A Concept Analysis”. European Journal of Contemporary Education, 9(2), pp. 337-349, 2020.

[15] E. B.-N. Sanders \& P. Stappers. "Co-creation and the new landscapes of design". Co-Design, $4(1), 5-18,2008$

[16] C. Elsen \& P. Leclercq. "SketSha" or the sketch power to support collaborative design Proceedings of CDVE: 21-25 September, 2008.

[17] C. Lallemand \& G. Gronier. Méthodes de design UX. Paris, Eyrolles, 2016. 